\title{
A multidimensional model of interaction as a framework for a phenomenon-driven approach to communication
}

\author{
Arto MUSTAJOKI \\ National Research University "Higher School of Economics" \\ Moscow, Russia \\ University of Helsinki \\ Helsinki, Finland
}

\begin{abstract}
Interaction between people is a cornerstone of being human. Despite huge developments in languages and communicative skills, interaction often fails, which causes problems and costs in everyday life and work. An inability to conduct dialogue also produces conflicts between groups of people, states and religions. Therefore, there are good reasons to claim that miscommunication and failures in interaction are among the most serious problems in the world. Researchers from different fields - linguistics, sociology, anthropology, psychology, brain research, philosophy - have tried to tackle this complex phenomenon. Their method-driven approaches enrich our understanding of the features of interaction in many ways. However, what is lacking is an understanding of the very essence of interaction, which needs a more holistic, phenomenon-driven approach. The aim of this paper is to show that the only way to reach this goal is multidisciplinarity, that is, using the results and methods of different fields of research. This is not an easy goal and task because the way of thinking and doing research varies greatly discipline-wise. A further obstacle is the researchers' training, which, as a rule, focuses on the tradition of only one field of research. The Multidimensional Model of Interaction provides a good framework for a more holistic approach to interaction by viewing the complex phenomenon from different angles. The model includes various phases of the process of interaction, beginning with the choice of the topic by the speaker and ending with identification of the reference by the recipient, as well as the mental worlds of the interlocutors (knowledge, attitudes, values, emotional state etc.), recipient design (accommodation of speech) and external circumstances.
\end{abstract}

Keywords: interaction, phenomenon-driven research, multidisciplinarity, multidimensional model of interaction, miscommunication

\section{For citation:}

Mustajoki, Arto. 2021. A multidimensional model of interaction as a framework for a phenomenon-driven approach to communication. Russian Journal of Linguistics 25 (2). 369-390. DOI: https://doi.org/10.22363/2687-0088-2021-25-2-369-390 


\title{
Многомерная модель взаимодействия как основа феномено-ориентированного подхода к коммуникации
}

\author{
Арто МУСТАЙОКИ
}

\author{
Национальный исследовательский университет «Высшая школа экономики» \\ Москва, Россия \\ Хельсинкский университет \\ Хельсинки, Финляндия
}

\begin{abstract}
Аннотация
Взаимодействие между людьми - основа принадлежности к человеческому роду. Несмотря на огромные изменения в языках и коммуникативных навыках, интеракции часто оказываются неудачными, что создает проблемы в быту и на работе. Неспособность вести диалог тоже человеческая черта, которая продуцирует конфликты между людьми, государствами и религиями. В связи с этим есть основания утверждать, что ошибки и сбои в коммуникации относятся к числу самых серьезных проблем мира. Ученые из разных областей знания участвуют в изучении этого сложного явления - лингвистики, социологии, антропологии, психологии. Их подходы, ориентированные на исследовательские методы, во многом обогащают наше понимание различных аспектов интеракции. Однако этим подходам недостает понимания самой сути интеракции, для чего необходим более холистический подход, ориентированный на явления. Цель данной статьи - показать, что единственный способ достичь этой цели - мультидисциплинарность, то есть использование результатов и методов различных областей исследования. Это непростая задача, потому что способы мышления и проведения исследования в разных науках отличаются друг от друга. Еще одно препятствие - обучение исследователей, которое, как правило, опирается на традиции только одной научной дисциплины. «Многомерная модель взаимодействия» обеспечивает хорошую основу для системного холистического подхода к взаимодействию, давая возможность рассмотреть это сложное явление с различных точек зрения. Модель включает различные фазы процесса вазимодействия, начиная с выбора темы со стороны говорящего и заканчивая определением референции со стороны реципиента, а также ментальные миры собеседников (знания, отношения, ценности, эмоциональное состояние и т.д.), приспособление речи к реципиенту (реципиент-дизайн) и внешние обстоятельства.
\end{abstract}

Ключевые слова: интеракция, феномено-ориентированное исследование, мультидисциплинарность, многомерная модель интеракиии, коммуникативные неудачи

\section{Для цитирования:}

Mustajoki A. A multidimensional model of interaction as a framework for a phenomenondriven approach to communication. Russian Journal of Linguistics. 2021. Vol. 25. № 2. P. 369-390. DOI: https://doi.org/10.22363/2687-0088-2021-25-2-369-390

\section{Introduction}

Interaction between people is the very foundation of being human. It is also a prerequisite of an active modern society. Consequently, researchers from different fields have tried to understand what emerges when two or more people meet. Researchers, be they linguists, sociologists, anthropologists, psychologists or philosophers, use their scientific education and sophisticated methodologies in 
trying to understand this fundamental principle of humankind. Their method-driven and discipline-oriented approaches have enriched our understanding of interaction in many ways. However, the knowledge is fragmented and reveals only one aspect at a time of the very complex intercourse between people.

To have a more truthful picture of human interaction, I suggest taking a holistic and multidisciplinary view of it (cf. Mustajoki 2017a). The idea of a wider perspective as such is not new. Edda Weigand claims that linguistics moves from searching for 'the simple' towards challenging 'the complex' (Weigand 2004: 3), or from 'reductionism' to 'holism' (Weigand 2011). Similar ideas are introduced in Istvan Kecskes's 'socio-cognitive approach' (Kecskes 2010). The aim of this paper is to show what such a more holistic approach to interaction could be.

In fact, the need of a wider multidisciplinary approach in linguistics is part of a larger current tendency. Everywhere in the world, researchers are called to solve the grand challenges of humankind, often called wicked problems (see an overview in UIA 2000). The list of these global concerns usually consists of such phenomena as climate change, pollution, energy supply, pandemics and the ageing of the population. According to a general view, solving these worldwide problems is possible only through the joint efforts of researchers from different fields. Such an approach has fundamental consequences for the way research is carried out. Monodisciplinary method-driven and discipline-centred research is not enough, because the resolution of wicked problems is possible only by applying a more holistic, phenomenon-driven approach.

In my view, the topic of this article could and should be added to the list of the biggest problems of humankind. Communication failures and disturbances in interaction are common everywhere: at home and work places, in parliaments, streets and conference venues. They take place between individuals, groups of people and states. Boaz Keysar (2008: 278) puts it very clearly when arguing that misunderstandings do not happen just occasionally because of noise in the system, but are "a product of how our mind works". The consequences of miscommunication produce human, economic and ethical problems and losses.

A holistic view on human interaction is not possible if we only adhere to the visible verbal side of interaction. Therefore, we have to go beyond language and linguistics and enter the territories of other disciplines. In doing this, we inevitably have to take into consideration that interaction is a very complex phenomenon with several intertwined factors present at the same time. That makes it difficult to determine the influence of each of them, which is a challenge for a research methodology. In order to identify the relevant phases and elements of a dialogue, I will refer to the Multidimensional Model of Interaction (MMI; Figure 1). It serves as a theoretical framework enabling discussion of the choices made by the communicants during an interaction, as well as the motivation behind them and the consequences caused by them. This unavoidably leads to a discussion about possible methods of examining various factors that determine the way people interact. The methodological issue will be touched on in Section 2, and then in Section 3, a more systematic review of it will be made. 


\section{The Multidimensional Model of Interaction}

Before describing the Multidimensional Model of Interaction, it is necessary to comment on some of its features. First, a model is always only a simplified approximation of reality. It is built for a better understanding of the essence of a certain phenomenon. This is true also for the MMI. In real interactional situations, various phases of speech production and comprehension overlap, and the process of sending and receiving a message is not always strictly linear. However, to examine the role of each factor in the process, we have to see each as a separate entity.

A further important comment on Figure 1: interaction is very much built as a joint interplay of participants where their roles change all the time, as pointed out by many researchers (e.g. Grice 1975, Clark 1996). Therefore, it is important to note that the figure does not illustrate an entire dialogue, but its smallest entity, a quantum, in which a speaker says something to a recipient, who tries to comprehend the sent message. The entire dialogue consists of a chain of such quanta. What follows from this is that in examining a quantum, we have to take into consideration the larger whole of which it is part.

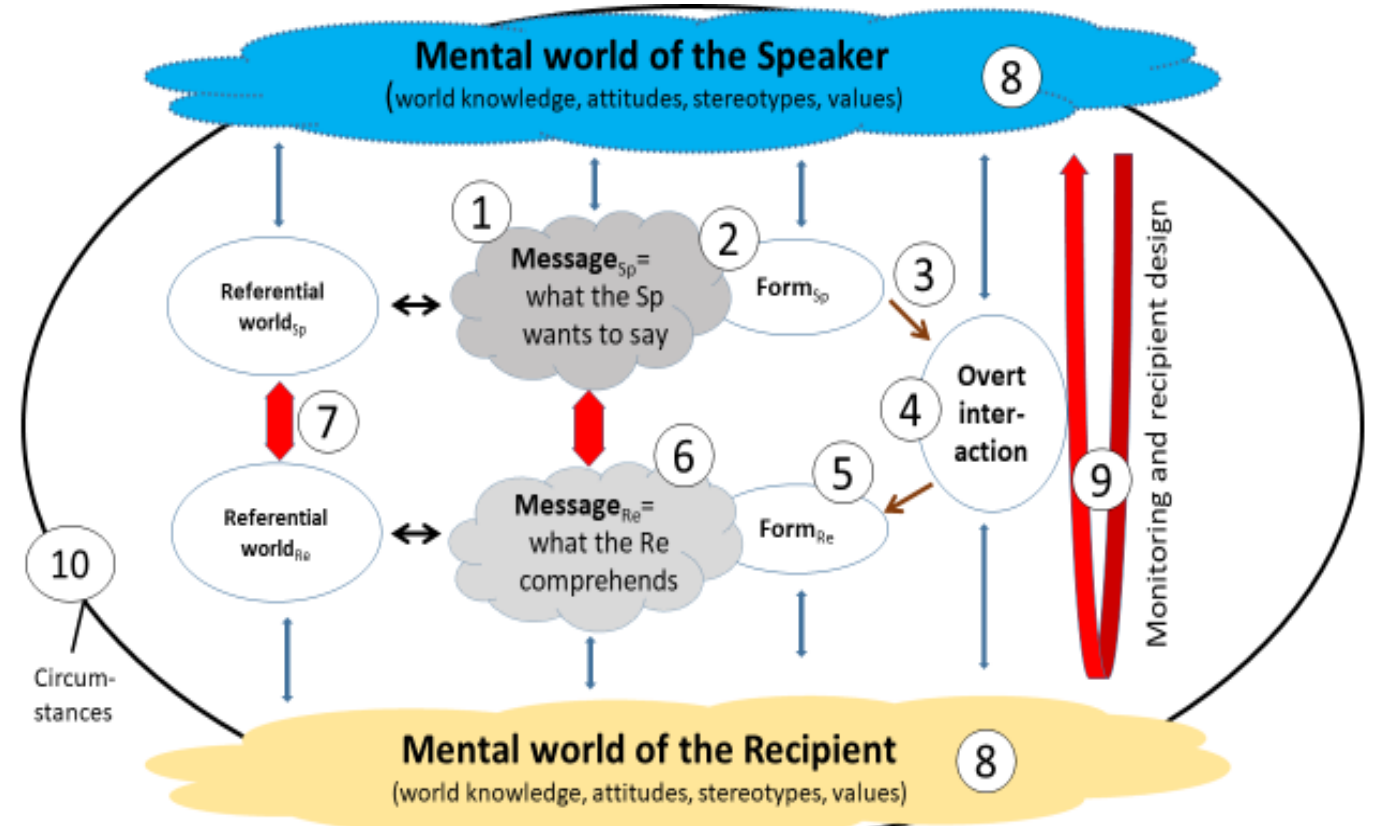

Figure 1. Multidimensional Model of Interaction

(cf. earlier versions in Mustajoki 2012, 2013, 2017b, Mustajoki \& Baikulova 2020)

One more thing about the model. As can be easily seen, the inner part of the figure (Items 1 to 7), drawn as an oval, resembles the famous information theory model of Shannon and Weaver, especially its newer modifications (e.g. Dobrick 1985: 97, Falkner 1997: 88). However, there are some relevant differences as well. First, the oval itself reflects the general idea of interaction better than previous linear 
presentations. It is true that interaction advances in time, but from the point of view of the interlocutors, the message sent by the speaker will then be rebuilt in the recipient's mind. Technically, the successfulness of the quantum of interaction depends on the extent of the similarity of the message sent by the speaker to the interpretation made by the recipient (Item 6), including the identification of the reference (Item 7).

A further distinctive feature of the model in comparison to many others is how it differentiates between various phases in speech production and perception. This enables the consideration of problems of interaction in more detail. We will return to the oval core of the figure below. Before that, we will examine the outer factors, which have a vital influence on the way people interact. All these elements circumstances, recipient design and mental worlds - are mentioned in the literature on interaction, but usually only as separate factors. The aim of the model is to put them into a coherent whole.

\subsection{Circumstances}

The outermost factor presented in Figure 1 is the circumstances (Item 10), that is, the conditions in which the interaction takes place. This factor may seem trivial because it is obvious and in some sense technical. However, it deserves attention because it substantially influences the course of interaction but is often ignored in recordings and transcripts of dialogues.

The most obvious part of the circumstances is the physical environment. The speaker often notices noises caused by machines, children playing, music, traffic or a crowd, but nevertheless, underestimates their effect on the hearing and perception of speech. Another technical obstacle is the distance between interlocutors, which hinders understanding in settings where the speaker does not realise that the recipient is no longer or not yet in a place where he can hear the speaker. This frequently happens in domestic environments (Mustajoki \& Baikulova 2020).

An important characteristic of interaction is the number of interlocutors. Gus Cooney et al. (2020) list features which are different in a group conversation in comparison to a dyadic one: (1) less "airtime" per person means more competition for it between interlocutors, (2) turn-taking becomes more complex, and (3) listeners have fewer opportunities to give feedback. When the number of participants increases, recipients are more hesitant to interrupt the speaker, which means that more moments of non-understanding remain ignored without correction.

The timeframe for a conversation may be short or long, but it is always limited. Adults have learnt to regulate their speech in accordance with the time available for conversation by intuitively bearing in mind the maxim of quantity. So, depending on the situation, answers to questions such as How was your holiday? can vary on a large scale from a very short reaction (Quite nice) to detailed stories about funny incidents and rare experiences. People know, on some level of awareness, that too long a story is boring, and a story that is too truncated is non-understandable, but they pay attention to this mostly only when other people are speaking. However, as 
is the case with all maxims, the maxim of quantity is often broken. Additionally, the right amount of speech seems to be different for a speaker who is eager to tell something and for a recipient who is waiting for his turn in a dialogue. The ability to regulate one's speech according to the available timeframe is important in both everyday conversation and institutional settings, for example, in meetings and interviews.

A substantial component of the circumstances derives from the composition of the interlocutors: how familiar they are with each other, and what their backgrounds and feelings are. This leads us to the next topic, Item 8 .

\subsection{The mental worlds of interlocutors}

Communicants' mental worlds (Item 8) play a crucial role in interaction. In the MMI, mental world is used as an umbrella notion for the wide range of various capacities, experiences and beliefs the interlocutors bring to the communication situation. For the sake of clarity, various characteristics of the mental world are discussed in three blocks: communicative tools, the mind and brain capacity. The distinction is partly artificial because communicative tools can be seen as a part of the mind, and the mind may be placed in the brain. However, as will be seen, these elements also have their own specific features.

Communicative tools. Let us start with the most obvious, language. Even in the case of a native tongue, people do not know the "entire" language. Therefore, interlocutors' linguistic capacities are never identical. It is clear that the vocabulary of a Moscow student differs greatly from that of a pensioner from Sakhalin Island. However, big differences can also be seen in the number of words Moscow students know and use (Polikarpov 2012). When interlocutors are different enough, they often realise their differences in knowing words, but nevertheless the speaker regularly fails to consider whether the words known by her are known also by others.

Communicative or pragmatic competence consists of a great amount of words (vocabulary), the ability to construct phrases from them (grammar) and a vast variety of skills which enable people to make the right choices and moves in the course of interaction: when to speak, which topic to touch on, how and to whom to express one's feelings, how to use indirect speech acts, how to react to nonunderstanding, and myriads more (see Padilla Cruz 2018, Mazzarella \& Pouscoulous 2020, and the literature there). A better term for this could be the communicative toolbox (cf. Rakic \& Maass 2019: 69). This emphasises the practical character of this fundamental element of interaction. In each communicative setting, interlocutors need a repertoire of communicative tools specific to that particular situation. A person who is brilliant in trade negotiations may be helpless in trying to conduct a dialogue in a bar with a person from the street - and vice versa.

The metaphor of a communicative toolbox concerns both verbal and nonverbal instruments. Bruno Bara (2011: 444-445) sees the main difference between 
them not in the external format of the tool but in the characteristics of the symbols they use. The linguistic part of communication is built on a system of hierarchically interlinked symbols, while extra-linguistic communication relies on a set of autonomous symbols. There is also a difference in the level of being conscious of using these tools. Extra-linguistic tools are used almost exclusively in an automated mode, while the usage of linguistic tools provides more options for deliberative discretion.

The idea of a toolbox means that if a certain instrument is not there, you cannot use it. In fact, the overall theoretical communicative capacity as such is not decisive for pragmatic competence but the quick availability of needed words, structures or skills. Usually communicants have only a second or two to make their choices. Therefore, it is not enough that a certain word or manner of communicative behaviour exists in the toolbox if the user is not able to find it in the time limit the situation allows.

A central instrument in the speaker's toolbox is the ability to adjust speech to the audience, or recipient design: this will discussed in more detail below after a journey to the mind and the brain.

The mind. Words and other linguistic elements are units of the personal idiolects of interlocutors, while the concepts behind them are constituents of her or his mind. Even when different people use the same words, they often mean different things. Adjectives and abstract nouns are especially vague. A long journey, warm weather and a good president have different interpretations in communicants' minds. If two persons or groups of people support democracy, it is almost guaranteed that they do not give the same meaning to this concept. More concrete concepts, such as "home", "holiday" or even "stone", may also have various interpretations, which is a challenge for mutual understanding (see e.g. Nickerson 1999, Mustajoki 2012, Hautamäki 2020).

Culturally specific concepts have gained much attention in literature on intercultural communication. Other popular topics in cultural comparisons are values, mindsets, mentality and communicative behaviour. Cultural differences can be seen only in comparison at a statistical level as a certain probabilistic phenomenon. Further, people differ from each other as individuals. However, the way we speak to a person does not derive from her or his actual characteristics but from our impression of that person in our minds (cf. van Dijk 2006:159-176, Mazzarella 2013: 41). If we believe that the person we are talking to does not want to discuss the coronavirus situation, we avoid this topic of interaction regardless of whether this is true or not.

Attitudes and stereotypes play a significant role in people's communicative behaviour. When the name of a known person (a relative, friend, celebrity) or a person belonging to a certain group of people (Russians, Blacks, teachers, Harley Davidson owners), an institution (a sect of a church, a political party, a university), a kind of sports or a branch of arts appears in a discussion, it inevitably creates some preconceptions, assumptions and prejudices in the interlocutors' minds. 
Participants' attitudes are not always expressed directly but come out in the way they speak. You are unlikely to say I don't like when they recruit immigrants to our office, but you might say The new immigrant in our office is quite a nice chapwhich reveals that this is a surprise to you. Stereotypes and the problems caused by them in interaction have been the object of many studies (see e.g. Greenwald \& Mahzarin 1995, Fiske et al. 2009).

Both the physiological and emotional states of interlocutors influence the way we speak and comprehend speech (cf. Peräkylä \& Sorjonen 2012, Mackenzie \& Alba-Juez 2019). Feelings and moods derived from these external factors reduce people's concentration on interaction. This emerges in the narrowing of people's viewpoints and an increase in egocentric behaviour.

The brain. Besides the mind as a rather wide and unclear entity, some features of the human brain make a more concrete, sometimes even measurable factor of influence on people's behaviour in interaction. Although the human brain has an astonishing capacity with its flexible structure and a huge amount of knowledge, it also has its limitations. The brain is very effective at harvesting pieces of information from its surroundings, but it can process only a small fraction of it (see Mustajoki 2017b and the literature there). Therefore, it has to save cognitive energy whenever it is possible and reasonable (Bargh \& Chartrand 1999). Cognitive busyness has substantial consequences on interaction (Gilbert et al. 1988). In concrete terms, this leads to automated processes and insufficient concentration on interaction, both of which easily cause communication failures. When considering the influence of these factors, we have to bear in mind the heavy time pressure present in most interactional settings.

The speaker saves cognitive energy by always speaking in the same way (Kecskes 2017). We all have our favourite words, phrases and constructions, which can be easily and quickly found when we produce speech. This is especially important in situations where cognitive busyness is present - and it often is in real life. The recipient saves cognitive energy by not concentrating on listening. This is naturally not the only reason for being an incompetent recipient. A recipient may also close his ears when he is not interested in the topic the speaker has chosen or if he has something important to think about at the same time. All in all, the restrictions of the brain cannot be overlooked when we try to understand what really happens in interaction.

\subsection{Recipient design and monitoring}

Item 9 in the figure refers to an essential element of interaction, namely recipient design (Newman-Norlund et al. 2009, Blokpoel et al. 2012, Mustajoki 2012). Other terms used in this connection are audience design (Sacks \& Schegloff, 1979; Horton \& Gerrig, 2002), accommodation (Palomares et al., 2016) or just tailoring (Pierce-Grove, 2016). Katrina Bremer and Margaret Simonot (1996) regard recipient design as the main tool in achieving communicative goals and preventing problems in understanding. The monitoring of the recipient's reactions 
is an important prerequisite for it (Clark \& Krych, 2004). "In interaction, interlocutors adapt to one another, consciously or unconsciously", as Jessica Gasiorek and her colleague put it (Gasiorek et al. 2019: 294).

Individualisation of speech by adjusting it to the current situation is an important tool in reaching (sufficient) understanding, and therefore, its absence is a substantial risk factor. But on the other hand, conducting recipient design, especially in situations new to the speaker, requires cognitive effort. Therefore, the speaker has to find a reasonable balance between energy consumption and the risks to non-comprehension of her speech by the recipient (cf. Sperber \& Wilson 1986, Do et al. 2020). As a rule, people are ready to put more effort into interaction in situations which are rare and important. It is possible to compensate for communication problems caused by differences in background knowledge with intensive recipient design. This explains the paradoxical claim according to which communication failures are less common in interaction with strangers than in everyday life (Ermakova \& Zemskaya 1993, Mustajoki 2013, 2017b).

People perform recipient design all the time when interacting. A striking example is when people speak to small children. An automated switch to baby talk immediately happens in everyone's speech. However, the overall ability to conduct recipient design varies. Sellers have stable routines in their way of speaking, but if they are skilful, they can individualise their speech according to their impression of the current customer. When we sell our ideas or desires to someone, we express our thoughts more carefully than usual and try to convince the recipient with tools which are calibrated for the conversation with him.

Speakers also make some general presumptions about the "other minds" they are dealing with. In categorising these mental states of others, people tend to use two dimensions: experience (the capability to sense and feel) and agency (the capacity to plan and act). People do not always ascribe a state of mind to other people, but on the other hand, they do ascribe a state of mind to non-humans (plants, gods, computers; Gray et al. 2007, Waytz et al. 2010). In fact, speaking to a nonhuman is a rather common phenomenon (Mustajoki et al. 2018). This may also cause problems in interaction. If someone using a computer says Where is my file!? with irritation in his voice, it is difficult for the person sitting in the same room even if that person is located at a distance from the speaker to comprehend whether this is a request for help or just an annoyed reaction.

In general, speakers often do not conduct recipient design at all or conduct it in an insufficient manner. There are several reasons for inadequate recipient design. A significant background factor here is people's egocentrism. We see the world through our own lenses (Kruger et al. 2005; Epley 2008, Keysar 2008, Kecskes \& Zhang 2009, Todd et al. 2015). Most people have the ability to feel empathy, and we may know approximately what other people know and think, but the speaker can never be sure about the recipient's knowledge of the question at hand, as well as about his motivations and desires concerning the current interactional situation.

A further factor which reduces the level of recipient design is the speaker's cognitive load (see e.g. Roßnagel 2000; Vogels et al., 2020). When emotional or 
physiological worries fill people's minds, less space is left for maintaining recipient design. Another obstacle may be a lack of the skills needed to conduct appropriate recipient design. This often occurs, for example, when specialists, e.g. doctors and IT workers, explain something to a layman. One problem in conducting recipient design is people's unawareness of the way in which they speak. "Speakers ... tend to overestimate how effectively they communicate, believing that their message is understood more often than it really is. ... Most people, most of the time, think that what they say is pretty clear", as Keysar (2008: 277) puts it.

\subsection{The speaker's work}

Now we start, step by step, to examine interlocutors' behaviour in the course of a dialogue using the inner oval of Figure 1 (Items 1 to 3). As was mentioned, we consider the smallest unit, a quantum of interaction, in which a speaker says something to a recipient. The first choice for the speaker is to decide whether to say something or not. If the speaker decides to go ahead, she has to select the topic. The speaker can choose between two main options. In the middle of an interaction, the speaker is often in a position where a reaction to the previous dialogue is expected. Of course, the speaker can always ignore what was said previously and start a new topic, but for this, the speaker should have special deontic rights (see e.g. Stevanovic \& Peräkylä 2012) or else this would be impolite. Another option is to have a totally open space for saying (almost) anything. This would happen at the beginning of a dialogue or entail a separate reaction to something which is happening nearby. The choice of topic is very much determined by the needs of the speaker. It is not reasonable to start to tell a complicated joke or explain how a computer programme works if there is time only for a short comment.

Practical and emotional needs, the desire to receive a concrete piece of knowledge, support or compassion are good reasons to speak to someone. On the other hand, sometimes it is wise to speak without a concrete goal just to keep a discussion alive. In addition to this, the speaker usually wants to say something which is also relevant to the recipient and show him that she is also interested in his interests.

Besides these general needs and rules of behaviour, the speaker may have more specific speech strategies. First, she usually, consciously or unconsciously, chooses between convergent, neutral and divergent strategies (Gallois et al. 2005). Consider the following situation. Tamara, a student of Moscow State University, is visiting her grandfather Viktor, who is living in Barnaul, a city in Southern Siberia. He is a committed supporter of Putin, while she finds Putin's way of ruling to be authoritarian and non-democratic. Tamara has to decide, consciously or unconsciously, which speech strategy she will take. A convergent strategy would entail sympathetic attitudes towards her grandfather's opinion, while a divergent strategy would lead to unpleasant debate and open conflict. A neutral strategy would be avoidance of the whole topic - if possible. 
Technically, the choice of the topic or content is followed by the next choice: how the speaker words what she wants to express. The situation and the participants of the dialogue determine how the speaker takes into consideration the needed register, scale of politeness and degree of recipient design.

Sometimes there are rather sophisticated differences in the usage of abstract or concrete notions when we comment, positively or negatively, on people's behaviour. If a person belongs to our group, we tend to use abstract expressions to describe positive characteristics and concrete ones when speaking of negative features. When speaking of out-group members, the opposite is true. So if John is one of "ours", we usually say He is helpful (positive information) and He hit Jack (negative information). If Jack belongs to "those", people tend to prefer another wording and say He helped John and He is aggressive (Maass 1999).

After the speaker has selected the content (message) and form, she gives the phrase a phonetic form (Item 3). Here both permanent defects of speech and occasional unclear pronunciation, such as mumbling or swallowing part of a phrase or word, are possible. The latter is rather frequent both in everyday interaction and in foreign language speech, albeit for different reasons. In the former case, it may be caused just by not concentrating on the interaction (Mustajoki 2017b) or by hiding something (Brennan \& Schober 2001). When speaking in a foreign language, the reason for unclear pronunciation is often a lack of confidence of whether the proposed word is correct or not (Martinez 2018).

The next stage (Item 4) is the only overt part of the process, when the set of sounds produced by the speaker move through the air to the ears of the recipient. The observable outcome of the speaker's work has been an object of intensive research in interactional research. The recipient's obligations begin after the overt part of the interaction.

\subsection{The recipient's work}

When the recipient begins his work (Items 5 to 7), the first thing is to recognise the set of sounds sent by the speaker. Speech does not travel as such to the reception centre of the recipient's brain, but is produced by it. Therefore, slips of the ear and other errors are possible, even frequent. Their general mechanism comes from an active prediction process which is happening continuously in the recipient's brain. This feature helps the recipient to comprehend speech as quickly as possible and what is just as important - to save time for his own turn. A possible risk is overguessing. In overguessing, the recipient fabricates something which he has not heard. As a rule, the beginning of a phrase would in this case still be in accordance with the speaker's message, but the rest is a result of the recipient's own imagination. Consider the following real life example taken from Mustajoki (2017b: 67). It illustrates well the "hear something, guess the rest" tactic: Peter is leaving for the grocery shop and stands at the door. Mary shouts to Peter: Are you still there? Bring some ... At this very moment, Peter remembers that he was just thinking of buying potatoes, but forgot to add this item to the shopping list. So the 
word potatoes becomes activated in Peter's mind, and while Mary goes on to say tomatoes, Peter hears that as potatoes - and buys potatoes instead of tomatoes.

In cases where no mishearings occur, plenty of other factors jeopardise proper understanding. The first obstacle comes from the fact that the speaker's message is not always very clear. "Communicators are neither always competent, nor always honest", as Mazzarella and Pouscoulous put it (2020: 2, emphasis in the original). A further issue is caused by the mind wandering. Killingworth and Gilbert (2010) claim that the mind wanders on average $46.9 \%$ of the time people are awake. Obviously, it is easier for a recipient to be mentally absent from the current situation than for a speaker.

In most cases, the usage of indirect or underspecific speech with multiple meanings is not a big problem for understanding. If a father or mother says to their child who is going outside that the bin is full, their meaning is clear to both interlocutors - it is another issue whether the youngster wants to understand it literally and not as a request. Here is one example of the use of underspecific speech: if one says John and Joan went to the cinema, the phrase as such does not reveal that they went to the same showing of the same film at the same time and together, but $99 \%$ of real communication situations refer to such a situation.

Various mechanisms help the recipient to determine the real meaning in a speaker's message. One mechanism is to identify whether there is something behind the choice of the topic by the speaker. Consider the following situation. Mary reads aloud to Peter a piece of Internet news about good results in using zinc to treat a cold. This may sound like a rather neutral and innocent topic of speech. However, the topic may have a certain history in the interlocutors' lives. If the question of the effect of zinc has been discussed by them earlier, that would explain why the speaker has chosen this particular item among thousands of other possible pieces of news. Depending on the interlocutors' opinions about this issue, the speaker may want to say As you see, I was right or It is awful that they publish such rubbish. Sometimes the real purpose of raising a particular topic for discussion is not obvious and can remain unnoticed to both the recipient and an external observer.

The recipient has to decide the level of seriousness of the message he hears from the speaker. According to his interpretation, he then chooses a suitable way to react to the message. Let us suppose that a speaker has just arrived home after a working day (Mustajoki 2017b: 63). She says to her spouse sitting in the living room Our boss is awful. He launches new ways to watch the effectiveness of our work all the time. I cannot stand it anymore. The brain of the recipient makes a quick analyses of the situation. On this basis, he selects a reaction which seems to him the most suitable for this situation. Possible reactions are, for example, to say a few comforting words, to propose to her that he will make dinner tonight, to start discussing whether she should find another job or not to say anything. If we record such a situation, we see which of these reactions is realised, but we get no understanding about the motivations of this choice, for example, how it was influenced by earlier similar situations. 
An important task in the recipient's work comes from processing moments in which he does not fully understand what the speaker is trying to say (Roberts et al. 2016). Much experimental evidence and many examples of real communication show that recipients, in the case of non-understanding, ask for a clarification (see e.g. Macagno 2017, Gander 2018, Micklos et al. 2020 and the literature there). However, in everyday settings, this is often not the case. When the situation is not important to the recipient, he often leaves cases of non-understanding unsolved and misunderstandings unsettled (Linell 1995, Hinnenkamp 2001). There are several reasons for such an uncooperative "let-it-pass" strategy (Firth 2009). First, the topic and the content of the speaker's message do not interest the recipient, and there is no social pressure to be polite. Second, the recipient supposes that he will understand it later in the course of the conversation. Third, he thinks that has understood enough, for example, if the speaker tells him that she went on holiday in Palermo, the recipient knows that this is a city in Italy but does not know exactly where it is located. Fourth, the recipient does not want to show his ignorance. Such cases are a challenge for a researcher who is analysing the conversation, because he or she may not be able to identify the moments of non-understanding.

One mechanism called epistemic vigilance tries to detect the truthfulness of a message (Sperber et al. 2010, Mazzarella 2015, Padilla Cruz 2020). The mechanism takes into account the credibility of the speaker herself and the sources of information she is referring to. On the other hand, people often tend to approve halftruths, small deviations from the whole truth and even lies when it is profitable for themselves. Therefore, they are not against listening to juicy stories, flattering words and unjustified praises.

Item 7 demonstrates an additional important element of interaction, namely the question of the reference. This issue is a possible source of misunderstanding in all phrases which denote a certain object. Besides pronouns (he, they, that), included in these phrases are other deictic words (here, now), all common nouns (a chair, a ball, my colleague) and proper nouns (Joan, Browns). Misreference is one of the most frequent causes of miscommunication, especially in circumstances where people speak of very practical and situation-bound matters, as in family discourse (Mustajoki \& Baikulova 2020).

\section{Methodological pluralism}

By definition, scientific research is based on evidence. The task of a researcher is to collect data, to analyse it and then to present the results to the academic audience. Each research branch has its own accepted and established methods of collecting and analysing data. These methods also demark the limits of research, although the research community does not necessary notice this. Some methodological issues have already been discussed above. This section presents a short review of methods used in interactional research (for more on the taxonomy of research methods, see Mustajoki 2017a).

Let us start with conversation analysis, which probably is the most used method in interactional research. The main aim of conversational analysis is to 
reveal details of the way people interact. An in-depth examination of authentic materials has revealed the regular structures of dialogue, for example, the rules of turn-taking, repairs and preference organisation (see overviews in Mazeland 2006, Liddicoat 2007). In its strict form, conversational analysis concentrates only on the observable part of interaction. What follows from this is the rejection of any speculative reasoning about interlocutors' mental worlds or conjoined history which often determine the successfulness of human encounters.

Conversational analysts, as a rule, concentrate on face-to-face dialogues. However, as the One Speaker's Day project of linguists based in St Petersburg shows, most interactional settings that people experience in their everyday life are unstructured, unplanned or even rather chaotic (Sherstinova 2015). If a researcher tries to identify them, a more sophisticated method is needed. The Retrospective Commenting Method is an attempt to tackle the weakness of other corpus-based methods by working on recorded one-day material later along with the informant. He or she can explain to the researcher what cannot be understood based only on the material. The method is quite laborious but enables a fuller picture of the factors influencing human interaction (Mustajoki \& Sherstinova 2017).

Philosophically oriented "armchair linguistics" can be regarded as the opposite of corpus-oriented interactional research (see e.g. Jucker \& Staley 2017). This label is given to the working method of linguists who merely rely on the intuition of a native speaker, practically, the intuition of the researcher her- or himself, and reject the usage of authentic materials. The intuitive knowledge of language serves as a laboratory where linguistic phenomena are tested. Noam Chomsky, the founder and greatest advocate of this approach, argues that going out of this box to the real world of interaction between people is not interesting, and even more: it is unscientific (cf. Andor 2004: 97, Mustajoki 2017a: 238). When armchair linguistics is used to study people's interactional practices, researchers create minimal pairs of phrases and contemplate their possible outcomes from the perspective of interlocutors involved in such a discussion. This method has, among others, opened our eyes to the problem of the distinction between "what is said" and "what is implicated/meant" and the common phenomenon usually discussed under the term underdeterminacy ("not all that is meant is said explicitly"; see reviews on these issues in Börjesson 2011, Haugh \& Jaszczolt 2012, Carston 2013). The method gives us answers about the possible theoretical outcomes of ambiguous and vague expressions and constructions, but not about what actually happens in interaction. There is also a vast scale of implicitness. Compare The car is dirty instead of Please, wash the car vs The Browns bought an electric car instead of Let's buy an electric car.

The brain is the motor of interaction. Therefore, it is a surprise that results of brain research are, as a rule, ignored in studies on human interaction. As shown in Section 2, the limitations of the brain have a fundamental influence on the way people speak and comprehend. The need to save cognitive energy, or miserliness in human cognition as Stanovic (2018) puts it, causes problems when interlocutors do this in the wrong way. 
Psychological experiments have also revealed dozens of cognitive biases such as the Linda problem or hindsight bias, which risk mutual understanding when they lead interlocutors astray in a very simple way, as shown for example in Kahneman (2011). If conversation analysis examines how people interact, psychological experiments can give answers about why people behave in the way they do. Through the eye-tracking method we can get evidence, for example, on how people handle ambiguous words (see e.g. Rabagliati \& Roberton 2016). Another widely used method is the N400 test, which gives evidence on the way the brain tries to predict the coming text (see e.g. Teidt et al. 2020). N400 tests show, for example, how the brain relies on probabilities and can be momentarily confused if I say that Grillasin makrilleja 'I grilled mackerels' instead of saying that Grillasin makkaroita 'I grilled sausages'.

Intercultural studies have a long history in research on the influence of differences in knowledge, mentality, attitudes and values on mutual understanding (see an overview in Spencer-Oatey \& Franklin 2009). In fact, these background factors are present in all types of interactional settings. People with different professions, confessions, hobbies and spheres of interests build their own cultures, which can include odd or unexpected elements. Even when interlocutors know each other well, there is a risk of a phenomenon called the common ground fallacy (Keysar \& Henly 2002, Mustajoki 2012, 2017b) or the false consensus effect (Clark 1996: 222): people overestimate their knowledge of the mental world of the recipient and do not conduct recipient design at all.

Ryan (2020) uses guided interviews to find out how L2 students learn to use referential words without causing misunderstandings. In a small study (Mustajoki 2006: 64-71), I collected people's metalinguistic comments about the way they interact. I was interested in instances where someone tells about how he or someone else has pretended to understand or not to understand. I found that people have good reasons to violate the principle of cooperation by being dishonest in their reactions.

Ethnography, the observation of interaction by a researcher, is sometimes the only way to get information about interaction. In fact, the largest Russian study on miscommunication is based on observations made by two linguists (Ermakova \& Zemskaya 1993). Being present in a set of communicative situations may be needed to understand the causes of communication failures. Consider the following situation from real life. A young man is going to move in with his girlfriend to their first common flat. His mother asks whether he needs something for the new home. He answers that a larger cooking pot would be nice. The mother says that they have an extra cooking pot in their summer cottage. She phones her father, who is living near the summer cottage, and asks him to go and get the cooking pot. He goes there but cannot find a single large cooking pot. He phones his daughter and tells her that. She asks him to send a photo of the pots he has found. After receiving the photos she realises that he has understood the size of the cooking pot incorrectly. This is not a "broken telephone" story because the message as such has not changed during the conversations. Thus, the cause of the communication failure is not mishearing 
or poor concentration on interaction, which are typical in everyday communication (Mustajoki \& Baikulova 2020). The misunderstanding derives from the conceptual differences between the interlocutors. For a young couple, "a larger cooking" pot means more than one litre, perhaps three, while in normal speech it refers to a five litre, perhaps even a ten litre cooking pot. The mother who was involved in the situation understood it correctly, but her father used the common sense definition of the object.

This far-from-complete overview already shows the wide pluralism in the use of various methods and approaches in interactional research. Each of them enables learning something new about human interaction, but none are sufficient for understanding it fully.

\section{Conclusion}

Human interaction is a very complex and multifaceted phenomenon. Therefore, if we want to understand the very essence of it, we have to approach it from different angles and apply the tools of various disciplines. The Multidimensional Model of Interaction provides a suitable framework for such phenomenon-driven research. It enables us to identify the factors influencing the course of interaction by providing instruments to answer not only what-questions but also why-questions. In this way we can deepen our understanding of the essence of human interaction.

In the contemporary world, researchers are under pressure to carry out research useful for people and society. Everything that helps us better understand problems in human interaction makes the world a better place to live. Therefore, linguists, together with psychologists, neuroscientists, sociologists, philosophers and anthropologists, should pay more attention to this issue despite its complexity - or in fact, because of its complexity.

(C) Arto Mustajoki, 2021
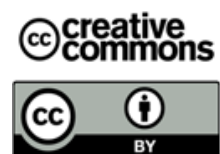

This work is licensed under a Creative Commons Attribution 4.0 International License https://creativecommons.org/licenses/by/4.0/

\section{Acknowledgement}

This article is an output of a research project implemented as part of the Basic Research Program at the National Research University Higher School of Economics.

\section{REFERENCES}

Andor, Jozsef. 2004. The master and his performance: An interview with Noam Chomsky, Intercultural Pragmatics 1 (1). 93-111.

Bara, Bruno G. 2011. Cognitive pragmatics: The mental process of communication. Intercultural Pragmatics 8 (3). 443-485. DOI: https://doi.org/10.1515/IPRG.2011.020 
Bargh, John A. \& Tanya L. Chartrand. 1999. The unbearable automaticity of being. American Psychologist 54. 462-476.

Blokpoel, Mark, Marlieke van Kesteren, Arjen Stolk, Pim Haselager, Ivan Toni \& Iris van Rooij. 2012. Recipient design in human communication: Simple heuristics or perspective taking? Frontiers of Human Neuroscience 6, article 253. DOI: https://doi.org/ 10.3389/fnhum.2012.00253

Börjesson, Kristin. 2011. The Notions of Literal and Non-literal Meaning in Semantics and Pragmatics. Dr. Dissertation. Universität Leipzig.

Bremer, Katrina \& Margaret Simonot. 1996. Preventing problems of understanding. In Katharina Bremer, Peter Broeder, Celia Roberts, Margaret Simonot \& Marie-Thérèse Vasseur (eds.), Achieving understanding: Discourse in intercultural encounters, 159-180. London: Longman.

Brennan, Susan E. \& Michael Schober. 2001. How listeners compensate for disfluencies in spontaneous speech. Journal of Memory and Language 44. 274-296. DOI: https://doi.org/ 10.1006/jmla.2000.2753

Carston, Robyn. 2013. Word meaning, what is said and explicature. In Carlo Penco \& Filippo Domaneschi (eds.), What is said and what is not, 175-204. Stanford: CSLI Publications.

Clark, Herbert H. 1996. Using Language. Cambridge: Cambridge University Press.

Clark, Herbert H. \& Meredyth A. Krych. 2004. Speaking while monitoring addressees for understanding. Journal of Memory and Language 50. 62-81. DOI: https://doi.org/ 10.1016/j.jml.2003.08.004

Cooney, Gus, Adam M. Mastroianni, Nicole Abi-Esber \& Alison Wood Brooks. 2020. The many minds problem: disclosure in dyadic versus group conversation. Current Opinion in Psychology 31. 22-27. DOI: https://doi.org/10.1016/j.copsyc.2019.06.032

Do, Monica L., Anna Papafragou \& John Trueswell. 2020. Cognitive and pragmatic factors in language production: Evidence from source-goal motion events. Cognitio 205. 10477. DOI: https://doi.org/10.1016/j.cognition.2020.104447

Dobrick, Martin. 1985. Gegenseitiges (Miss-)Verstehen in der dyadischen Kommunikation [Mutual (mis)understanding in a dyadic communication]. Münster: Aschendorff.

Epley, Nicholas. 2008. Solving the (real) other minds problem. Social and Personality Psychology Compass 2 (3). 1455-1474.

Ermakova, Olga \& Elena A. Zemskaya. On constructing a typology of communicative failures on the basis of authentic Russian material. In E.A. Zemkaya (ed.), The Russian language and its functioning: a communicative-pragmatic aspect, 90-157. Moscow: Nauka. (In Russ.)

Falkner, Wolfgang. 1997. Verstehen, Missverstehen und Missverständnisse: Untersuchungen an einem Korpus englischer und deutscher Beispiele [Understanding, misunderstanding and miscommunication: studies on the basis of corpus with English and German instances]. Tübingen: Niemayer.

Firth, Alan. 2009. The lingua franca factor. Intercultural Pragmatics 6 (2). 147-170. DOI: https://10.1515/IPRG.2009.009

Fiske, Susan T., Lasana T. Harris, Ann Marie Russell \& Nicole Shelton. 2009. Divergent social, realities, depending on where you sit: Perspectives from the stereotypes content model. In Stéphanie Demoulin, Jacques-Philippe Leyens \& John F. Dovidio (eds.), Intergroup misunderstandings: Impact of divergent social realities, 173-189. New York \& London: Routledge.

Gallois, Cindy, Tania Ogay \& Howard Giles. 2005. Communication Accommodation Theory: A look back and a look ahead. In William B. Gudykunst (eds.), Theorizing about intercultural communication, 121-148. Thousand Oaks: Sage. 
Gander, Anna Jia. 2018. Understanding in Real-Time Communication: Micro-Feedback and Meaning Repair in Face-to-Face and Video-Mediated Intercultural Interactions. PhD Dissertation. University of Gothenburg. Dept. of Applied Information Technology.

Gasiorek Jessica, Cindy Gallois, Herbert Pierson, Jon F. NussBaum \& Jake Harwood. 2019. Advanced theory in language, communication, and intergroup relations. In Jake Harwood, Jessica Gasiorek, Herbert Pierson, Jon F. NussBaum \& Cidy Gallois (eds.), Language, communication, and intergroup relations: A celebration of the scholarship of Howard Giles, 291-305. New York \& London: Routledge.

Gilbert, Daniel T., Brett W. Pelham \& Douglas S. Krull. 1988. On cognitive busyness: When person perceivers meet persons perceived. Journal of Personality and Social Psychology 54 (5). 733-740.

Gray, Heather M., Kurt Gray \& Daniel M. Wegner. 2007. Dimensions of mind perception. Science 315, 619. DOI: https://doi.org/10.1126/science. 1134475

Greenwald, Anthony G. \& Mahzarin R. Banaji. 1995. Implicit social cognition: Attitude, self-esteem, and stereotypes. Psychological Review 102 (1). 4-27.

Grice, H. Paul. 1975. Logic and conversation. In Peter Cole \& Jerry L. Morgan (eds.), Syntax and Semantics, vol. 3: Speech Acts. 41-58. New York: Academic Press.

Haugh, Michael \& M. Jaszczolt Kasia. 2012. Speaker intentions and intentionality. In Allan Keith \& Kasia M. Jaszczolt (eds.), The Cambridge handbook of pragmatics, 87-112. Cambridge: Cambridge University Press.

Hautamäki, Antti. 2020. A New Approach to Epistemological Relativism based on the Concept of Points of View. Helsinki: Springer.

Hinnenkamp, Volker. 2001. Constructing misunderstanding as a cultural event. In Aldo di Luzio, Susanne Günthner \& Franca Orletti (eds.), Culture in communication: Analyses of intercultural situations, 211-243. Amsterdam/Philadelphia: John Benjamins.

Horton, William S. \& Richard J. Gerrig. 2002. Speakers' experiences and audience design: knowing when and knowing how to adjust utterances to addressees. Journal of Memory and Language 47 (4). 589-606. DOI: https://doi.org/10.1016/S0749-596X(02)00019-0

Jucker, Andreas H. \& Larssyn Staley. 2017. (Im)politeness and developments in methodology. In Jonathan Culpeper, Michael Haugh \& Dániel Kádár (eds.), The Palgrave handbook of linguistic (im) politeness, 403-429. Palgrave, London.

Kahneman, Daniel. 2011. Thinking, Fast and Slow. London: Penguin Books.

Kecskes, Istvan. 2010. The paradox of communication: A socio-cognitive approach. Pragmatics and Society 1 (1). 50-73. DOI: https://doi.org/10.1075/ps.1.1.04kec

Kecskes, Istvan. 2017. Implicitness in the use of situation-bound utterances: From lexis to discourse. In Piotr Cap \& Marta Dynel (eds.), Implicitness: From lexis to discourse, 201-215. Amsterdam / Philadelphia: Benjamins.

Kecskes, Istvan \& Fenghui Zhang. 2009. Activating, seeking, and creating common ground: A socio-cognitive approach. Pragmatics \& Cognition 17 (2). 331-355. DOI: https://doi.org/ $10.1075 / \mathrm{p} \& \mathrm{c} .17 .2 .06 \mathrm{kec}$

Keysar, Boaz. 2008. Egocentric processes in communication and miscommunication. In Istvan Kecskes \& Jacob Mey (eds.), Intention, common ground and the egocentric speakerhearer, 277-296. Berlin: Mouton de Gruyter.

Keysar, Boaz \& Anne S. Henly. 2002. Speakers' overestimation of their effectiveness. Psychological Science 13. 207-212.

Killingsworth, Matthew \& Daniel T. Gilbert. 2010. A wandering mind is an unhappy mind. Science 330. 932. DOI: https://doi.org/10.1126/science.1192439

Kruger, Justin, Nicolas Epley, Jason Parker \& Zhi-Wen Ng. 2005. Egocentrism over e-mail: Can we communicate as well as we think. Journal of Personality and Social Psychology 89 (6). 925-936. DOI: https://doi.org/10.1037/0022-3514.89.6.925 
Liddicoat, Anthony J. 2007. An Introduction to Conversation Analysis. London: Continuum.

Linell, Per. 1995. Troubles with mutualities: Towards a dialogical theory of misunderstanding and miscommunication. In Ivana Marková, Carl Graumann \& Klaus Foppa (eds.), Mutualities in dialogue 176-213. Cambridge: University Press.

Maass, Anne. 1999. Linguistic intergroup bias: Stereotype perpetuation through language. Advances in Experimental Social Psychology 31. 79-121.

Macagno, Fabricio. 2017. Evidence and presumptions for analysing and detecting misunderstandings. Pragmatics \& Cognition 24 (2). 263-296. DOI: https://doi.org/ 10.1075/pc.17034.mac

Mackenzie, J. Lachan \& Laura Alba-Juez (eds.). 2019. Emotion in Discourse. Amsterdam: John Benjamins.

Martinez, Elyssa Kay V. 2018. A corpus-based analysis of tertiary students' communication strategies. International Journal of Trend in Scientific Research and Development 3 (1). $760-766$.

Mazeland, Harrie. 2006. Conversation analysis. In Keith Brown (eds.), Encyclopedia of language \& linguistics, $2^{\text {nd }}$ edn., volume 3, 153-163. Oxford: Elsevier.

Mazzarella, Diana. 2013. 'Optimal relevance' as a pragmatic criterion: the role of epistemic vigilance. UCL Working.Papers. Linguist 25. 20-45.

Mazzarella, Diana. 2015. Pragmatic and epistemic vigilance: The development of sophisticated interpretative strategies. Croatian Journal of Philosophy 15 (44). 183-199.

Mazzarella, Diana \& Nausicaa Pouscoulous. 2020. Pragmatics and epistemic vigilance: A developmental perspective. Mind \& Language 24 (2). 263-296.

Micklos, Ashley, Bradley Walker \& Nicolas Fay. 2020. Are people sensitive to problems in communication? Cognitive Science 44. e12816.

Mustajoki, Arto. 2006. The Integrum Database as a powerful tool in research on contemporary Russian. In Galina Nikiporec-Takigava (eds.), Integrum: tochnye metody i gumanitarnye nauki, 50-75. Moscow: Letnij sad.

Mustajoki, Arto. 2012. A Speaker-oriented multidimensional approach to risks and causes of miscommunication. Language and Dialogue 2. 216-242. DOI: https://doi.org/10.1075/ ld.2.2.03mus

Mustajoki, Arto. 2013. Risks of miscommunication in various speech genres. In Elena Borisova \& Olga Souleimanova (eds.), Understanding by communication, 33-53. Cambridge: Cambridge Scholars Publishing. https://helda.helsinki.fi/bitstream/handle/10138/39226/ Risks_of_miscommunication_in_various_speech_genres.pdf?sequence $=2$

Mustajoki, Arto. 2017a. The issue of theorizing: Object-of-study and methodology. In Edda Weigand (ed.), Language and dialogue: A handbook of key issues in the field, 234-250. New York: Routledge. https://helda.helsinki.fi/handle/10138/297726

Mustajoki, Arto. 2017b. Why is miscommunication more common in everyday life than in lingua franca conversation? In Istvan Kecskes \& Stavros Assimakopoulos (eds.), Current issues in intercultural pragmatics (Pragmatics and Beyond New Series), 55-74. Amsterdam/Philadephia: John Benjamins. DOI: https://doi.org/10.1075/pbns.274

Mustajoki, Arto \& Alla Baikulova. 2020. The risks of misunderstandings in family discourse: home as a special space of interaction. Language and Dialogue 10 (3). 340-368. DOI: https://doi.org/10.1075/ld.00074.mus

Mustajoki, Arto \& Tatiana Sherstinova. 2017. The "Retrospective Commenting Method" for longitudinal recordings of everyday speech. In Alexey Karpov, Rodmonga Potapova \& Iosif Mporas (eds.), SPECOM 2017, Lecture Notes in Artificial Intelligence, vol. 10458, 1-9. NewYork: Springer. https://link.springer.com/chapter/10.1007/978-3319-66429-3_71 
Mustajoki, Arto, Tatiana Sherstinova \& Ulla Tuomarla. 2018. Types and functions of pseudodialogues. In Edda Weigand \& Istvan Kecskes (eds.), From Pragmatics to Dialogue, 189-215. Amsterdam / Philadephia: John Benjamins.

Newman-Norlund, Sarah E., Matthijs L. Noordzij, Roger D. Newman-Norlund, Inge A.C. Volman, Jan Peter de Ruiter, Peter Hagoort \& Ivan Toni. 2009. Recipient design in tacit communication. Cognition 111. 46-54. DOI: https://doi.org/10.1016/j.cognition. 2008.12.004

Nickerson, Raymond S. 1999. How we know - and sometimes misjudge - what others know: Imputing one's own knowledge to others. Psychological Bulletin 125 (6). 737-759.

Padilla Cruz, Manuel. 2018. Pragmatic competence injustice. Social Epistemology 32 (3). $143-163$.

Padilla Cruz, Manuel. 2020. Evidential particles and epistemic vigilance. In Agnieszka Piskorska (ed.), Relevance Theory, Figuration, and Continuity in Pragmatics, 69-83. Amsterdam (Philadelphia): John Benjamins.

Palomares, Nicholas A., Howard Giles, Jordan Soliz \& Cindy Gallois. 2016. Intergroup accommodation, social categories, and identities. In Howard Giles (eds.), Communication Accommodation Theory: Negotiating Personal Relationships and Social Identities Across Contexts, 123-151. Cambridge: Cambridge University Press.

Peräkylä, Anssi \& Marja-Leena Sorojen (eds.). 2012. Emotion in Interaction. Oxford: Oxford University Press.

Pierce-Grove, Ri. 2016. Conclusion: Making the new status quo: social media in education. In Christine Greenhow, Julia Sonnevend \& Colin Agur (eds.), Education and Social Media: Toward a Digital Future, 239-246, Cambridge (Massachusetts), London: The MIT Press.

Polikarpov, A. O. 2012. On systemic relationship in the active part of word comprehension by individuals and society. In N. D. Golev (ed.), Everyday Metalinguistic Cognition: Ontological and Gnoseological Aspects, vol. 4, 175-189. Kemorovo: Kemerovskii gos. universitet. (In Russ.)

Rabagliati, Hugh \& Alexander Robertson. 2016. How do children learn to avoid referential ambiguity? Insights from eyetracking. Journal of Memory and Language 94. 15-27. DOI: https://doi.org/10.1016/j.jml.2016.09.007

Rakić, Tamara \& Anne Maass. 2019. Communicating between groups, communicating about groups. In Jake Harwood, Jessica Gasiorek, Herbert Pierson, Jon F. NussBaum \& Cindy Gallois (eds.), Language, Communication, and Intergroup Relations: A Celebration of the Scholarship of Howard Giles, 66-97. New York \& London: Routledge.

Roberts, Gareth, Benjamin Langstein \& Bruno Galantucci. 2016. (In)sensitivity to incoherence in human communication. Language \& Communication 47. 15-22. DOI: https://doi.org/ 10.1016/j.langcom.2015.11.001

Roßnagel, Christian. 2000. Cognitive load and perspective-taking: Applying the automatic controlled distinction to verbal communication. European Journal of Social Psychology 30 (3). 429-445.

Ryan, Jonathon. 2020. Under-explicit and minimally explicit reference: Evidence from a longitudinal case study. In Jonathon Ryan \& Peter Crosthwaite (eds.), Referring in a Second Language: Studies on Reference to Person in a Multilingual World, 100-118. London: Routledge.

Sacks, Harvey \& Emmanuel A. Schegloff, 1979. Two preferences in the organization of reference to persons in conversation and their interaction. In George Psathas (eds.), Everyday Language, 15-21. New York: Irvington. 
Sherstinova, Tatiana. 2015. Macro episodes of Russian everyday oral communication: Towards pragmatic annotation of the ORD speech corpus. In Alexey Ronzhin, Rodmonga Potapova \& Nikos Fakotakis (eds.), Speech and computer, SPECOM 2015. Lecture Notes in Computer Science, vol. 9391, 268-276. New York: Springer.

Spencer-Oatey, Helen \& Peter Franklin. 2009. Intercultural Interaction: A Multidisciplinary Approach to Intercultural Communication. Palgrave: MacMillian.

Sperber, Dan \& Deirdre Wilson (1986/1995). Relevance: Communication and Cognition. Oxford: Blackwell.

Sperber, Dan, Fabrice Clément, Christophe Heintz, Olivier Mascaro, Hugo Mercier, Gloria Origgi \& Deirdre Wilson. 2010. Epistemic vigilance. Mind and Language 25 (4). 359-393.

Stanovich, Keith E. 2018. Miserliness in human cognition. The interaction of detection, override and mindware. Thinking \& Reasoning 24 (3). 423-444. DOI: https://doi.org/ 10.1080/13546783.2018.1459314

Stevanovic, Melisa \& Anssi Peräkylä, 2012. Deontic authority in interaction: the right to announce, propose and decide. Research on Language \& Social Interaction 45 (3). 297-321. DOI: https://doi.org/10.1080/08351813.2012.699260

Tiedt, Hannes O., Felicitas Ehlen \& Fabian Klostermann. 2020. Age-related dissociation of N400 effect and lexical priming. Scientific reports 10, 20291. doi.org/10.1038/s41598020-77116-9

Todd, Andrew R., Matthias Forstmann, Pascal Burgmer, Alison Wood-Brooks \& Adam D. Galinsky. 2015. Anxious and egocentric. How specific emotions influence perspective taking. Journal of Experimental Psychology-General 144 (2). 374-391. DOI: https://doi.org/10.1037/xge0000048

Van Dijk, Teun A. 2006. Discourse, context and cognition. Discourse Studies 8. 159-176.

Vogels, Jorrig, David M. Howcroft, Elli Tourtouri \& Vera Demberg. 2020. How speakers adapt object descriptions to listeners under load. Language, Cognition and Neuroscience 35 (1). 78-92. DOI: https://doi.org/10.1080/23273798.2019.1648839

Waytz, Adam, Kurt Gray, Nicholas Epley \& Daniel M. Wegner. 2010. Causes and consequences of mind perception. Trends in Cognitive Sciences 14. 383-88. DOI: https://doi.org/10.1016/j.tics.2010.05.006

Weigand, Edda. 2004. Emotions: The simple and the complex. In Edda Weigand (eds.), Emotions in dialogic interaction, 3-31. Amsterdam/Philadelphia: John Benjamins.

Weigand, Edda. 2011. Paradigm changes in linguistics: from reductionism to holism. Language Sciences 33. 544-549. DOI: https://doi.org/10.1016/j.langsci.2011.04.031

\section{Internet resources}

UIA 2000 Encyclopedia of World Problems and Human Potential. http://encyclopedia. uia.org/en (accessed: 25 February 2021).

\section{Article history:}

Received: 10 February 2021

Accepted: 25 April 2021

\section{История статьи:}

Дата поступления в редакцию: 10 февраля 2021

Дата принятия к печати: 25 апреля 2021 


\section{Bionote:}

Arto MUSTAJOKI is Professor Emeritus at the University of Helsinki (Finland). He works as a leading research fellow in the national research university Higher School of Economics (Moscow). His research interests include contemporary Russian, the theory of functional syntax, corpus linguistics, the Russian mentality, the causes and consequences of miscommunication and research ethics. Mustajoki has also published various teaching materials for learning Russian and popularised books for the public. He is vice-president of the International Assosiation of Teachers of Russian language and literature.

\section{Contact information:}

University of Helsinki

Yliopistonkatu 4, 00100 Helsinki, Finland

e-mail: arto.mustajoki@helsinki.fi

ORCID: 0000-0002-6609-7090

\section{Сведения об авторе:}

Арто МУСТАЙОКИ - почетный профессор Хельсинского университета (Финляндия), главный научный сотрудник Национального исследовательского университета «Высшая школа экономики», вице-президент Международной ассоциации преподавателей русского языка и литературы (МАПРЯЛ). Сфера его научных интересов включает современный русский язык, теорию функционального синтаксиса, корпусную лингвистику, русскую ментальность, причины и последствия непонимания в коммуникации, исследовательскую этику. Он также является автором учебных материалов по русскому языку и научно-популярных книг.

\section{Контактная информация:}

University of Helsinki

Yliopistonkatu 4, 00100 Helsinki, Finland

e-mail: arto.mustajoki@helsinki.fi

ORCID: 0000-0002-6609-7090 